\title{
PENERAPAN MODEL PEMBELAJARAN PREDICT OBSERVE EXPLAIN (POE) DILENGKAPI LKS BERBASIS DRILL AND PRACTICE UNTUK MENINGKATKAN KEAKTIFAN DAN PRESTASI BELAJAR SISWA PADA MATERI HIDROLISIS GARAM KELAS XI IPA 3 SEMESTER GENAP SMA N 2 KARANGANYAR TAHUN PELAJARAN 2016/2017
}

\author{
Lisa Ariyanti, Budi Utami", dan Elfi Susanti VH \\ Program Studi Pendidikan Kimia, FKIP,Universitas Sebelas Maret, Surakarta, Indonesia \\ *Keperluan Korespondensi, telp: 081227973456, email: budiutami@staff.uns.ac.id
}

\begin{abstract}
ABSTRAK
Penelitian ini bertujuan untuk meningkatkan keaktifan dan prestasi belajar siswa kelas XI IPA 3 SMA Negeri 2 Karanganyar pada materi hidrolisis garam dengan menerapkan model pembelajaran Predict Observe Explain (POE) dilengkapi LKS berbasis drill and practice. Penelitian ini merupakan penelitian tindakan kelas yang terdiri dari dua siklus. Subyek penelitian ini adalah siswa kelas XI IPA 3 SMA N 2 Karanganyar tahun pelajaran 2016/2017. Data diperoleh melalui wawancara, observasi, tes, dan angket. Teknik analisis data yang digunakan adalah analisis deskriptif. Hasil penelitian menunjukkan bahwa penggunaan model pembelajaran POE dilengkapi LKS berbasis drill and practice dapat meningkatkan keaktifan dan prestasi belajar siswa pada materi hidrolisis garam. Peningkatan keaktifan dapat dilihat dari kenaikan presentase siswa sebesar $79,49 \%$ pada siklus I dan meningkat menjadi $92,31 \%$ pada siklus II. Prestasi belajar siswa dapat dilihat pada aspek sikap, pengetahuan, dan keterampilan. Berdasarkan hasil tes siklus I ketercapaian aspek sikap pada siklus I sebesar $82,05 \%$ dan meningkat menjadi $89,74 \%$ pada siklus II. Ketercapaian aspek pengetahuan siswa sebesar $51,28 \%$ dan meningkat menjadi $87,18 \%$ pada siklus II. Ketercapaian aspek keterampilan sebesar $87,18 \%$.
\end{abstract}

Kata Kunci : POE, LKS berbasis drill and practice, keaktifan, prestasi belajar, hidrolisis garam.

\section{PENDAHULUAN}

Pendidikan merupakan aspek penting dalam menentukan kualitas dan kelangsungan hidup suatu bangsa. Pendidikan menjadi salah satu indikator kemajuan suatu bangsa. Suatu bangsa akan dianggap maju jika kualitas pendidikannya tinggi. Kualitas pendidikan di Indonesia, yang merupakan negara berkembang, masih tergolong rendah. Hal ini dibuktikan oleh data dari OECD (Organization for Economic Cooperation and Development) diperoleh hasil bahwa Indonesia di tahun 2015 menempati peringkat ke-69 dari 76 negara yang ikut berpartisipasi dalam tes PISA. Negara-negara Asia seperti Malaysia menempati peringkat 52 , Thailand pada peringkat 47, Jepang peringkat 4, Korea peringkat 3 , dan Singapura pada peringkat 1 di tahun yang sama. Oleh karena itu, inovasi dalam dunia pendidikan perlu dilakukan untuk meningkatkan kualitas dari pendidikan agar dapat bersaing dengan negara lain. Pemerintah, dalam hal ini berupaya melakukan perbaikan dalam dunia pendidikan, baik melalui peningkatan kualitas pendidik, peningkatan kualitas sarana prasarana yang menunjang pendidikan, pembaharuan kurikulum dan usaha-usaha lainnya.

Guru, dalam melaksanakan tugas dan kewajibannya dalam dunia pendidikan, mempunyai rencana kegiatan yang diatur dalam sebuah kurikulum. Di Indonesia sendiri telah terjadi pergantian kurikulum secara berkesinambungan, hingga kini total ada 
11 kurikulum yang telah dilahirkan di Indonesia. Kurikulum yang diterapkan saat ini adalah Kurikulum 2013, yang didalamnya terdapat beberapa penyempurnaan pola pikir. Penyempurnaan pola pikir yang dimaksud dalam Peraturan Menteri Pendidikan dan Kebudayaan (Permendikbud, 2014) diantaranya adalah pembelajaran berpusat pada guru berubah menjadi berpusat pada peserta didik, pola pembelajaran pasif menjadi pembelajaran aktif-mencari, serta pola belajar sendiri menjadi belajar kelompok. Perubahan pola pembelajaran pasif menjadi pembelajarn aktif-mencari semakin diperkuat dengan model pembelajaran pendekatan ilmiah (scientific approach). Pembelajaran ini menekankan pada pengamatan, penalaran, penemuan, pengabsahan, dan penjelasan tentang suatu kebenaran.

SMA Negeri 2 Karanganyar merupakan salah satu sekolah yang menerapkan Kurikulum 2013. Sarana dan prasarana yang disediakan sekolah telah mengarah pada peningkatan aktivitas belajar siswa dalam mengikuti proses pembelajaran. Salah satunya sekolah ini memiliki fasilitas laboratorium yang cukup memadai untuk kegiatan pembelajaran, namun penggunaan fasilitas laboratorium ini kurang dimanfaatkan oleh guru di sekolah. Berdasarkan hasil observasi dan wawancara yang dilakukan pada tanggal 3 Januari 2017, guru hanya terbatas pada penggunaan metode ceramah, tanya jawab dan penugasan sehingga aktivitas siswa hanya terbatas mendengarkan, mencatat penjelasan guru dan mengerjakan penugasan yang diberikan oleh guru. Hal ini tentu membuat siswa cenderung pasif atau rendah aktivitasnya dalam pembelajaran karena pembelajaran hanya berpusat pada guru (teacher center learning). Proses pembelajaran dikatakan baik, bila proses tersebut dapat membangkitkan aktivitas belajar yang efektif [1].

Keaktifan siswa dapat menunjukkan seberapa tertarik siswa dalam mengikuti pembelajaran. Semakin aktif siswa dalam mengikuti pembelajaran maka pembelajaran yang berlangsung akan semakin efektif. Kelas XI IPA 3 merupakan kelas yang berada pada katogori kurang aktif. Sebenarnya beberapa siswa di kelas ini sudah terlihat cukup tertarik dengan pembelajaran kimia, namun jumlah siswa yang tertarik ini hanya sebagian kecil dari jumlah siswa yang ada di kelas.

Salah satu model pembelajaran yang memancing keaktifan dan melibatkan siswa yaitu model pembelajaran Predict Observe Explain (POE). Model pembelajaran POE dapat meningkatkan aktivitas dan prestasi belajar siswa [2]. Model pembelajaran POE cocok diterapkan untuk meningkatkan ketertarikan siswa yang berhubungan dengan pembelajaran sains [3].

Model pembelajaran POE bertolak dari teori kontruktivisme yang menekankan individu yang diharuskan secara aktif membangun pengetahuan dan keterampilannya. Sintaks model pembelajaran POE secara garis besar adalah prediksi yang dituliskan oleh siswa yang berkaitan dengan praktikum yang akan dilakukan atau didemonstrasikan (predict), pengamatan terhadap kegiatan praktikum atau demonstrasi yang dilakukan (observe), dan yang terakhir siswa mencoba melakukan dekonstruksi hasil demonstrasi atau percobaan dan menjelaskan mengapa hal tersebut terjadi (explain) [4]. Model pembelajaran POE dapat membuat siswa lebih aktif dalam bertanya dan dapat mengurangi kesalahpahaman siswa dalam menangkap materi [5]. Siswa juga akan lebih lama dalam mengingat suatu konsep karena melakukan pengamatan langsung.

Selain model pembelajaran, media pembelajaran juga sangat menentukan kualitas dari pembelajaran itu sendiri. Salah satu media yang dapat digunakan untuk membantu siswa belajar mandiri dan bisa meningkatkan kemampuan siswa dalam menganalisis soal adalah LKS yang berbasis drill and practice. Drill and practice sendiri tepat diterapkan dalam pembelajaran materi hitungan, dan peningkatan perbendaharaan katakata (vocabulary) [6]. LKS berbasis drill and practice ini dapat diterapkan pada mata pelajaran kimia khususnya untuk materi pokok hidrolisis yang melibatkan 
soal-soal hitungan dan hafalan yang mana dapat merangsang siswa untuk aktif berpikir, aktif berlatih menyelesaikan soal-soal dan aktif dalam proses pembelajaran. Karena pada dasarnya dengan latihan soal lebih banyak, jika menemui kesulitan siswa akan cenderung bertanya agar bisa paham.

\section{METODE PENELITIAN}

Penelitian ini merupakan Penelitian Tindakan Kelas (PTK) yang dilaksanakan dalam dua siklus. Setiap siklusnya terdapat empat tahapan, yaitu perencanaan, pelaksanaan, observasi, dan refleksi. Subjek penelitian adalah siswa kelas XI IPA 3 SMA Negeri 2 Karanganyar tahun pelajaran 2016/2017. Pemilihan subjek dalam penelitian ini didasarkan pada hasil observasi yang dilakukan pada saat prasiklus, dimana subjek yang dipilih tersebut teridentifikasi mempunyai permasalahan dalam pembelajaran yaitu keaktifan dan prestasi belajar yang rendah.

Data yang dikumpulkan meliputi data tentang keadaan siswa yang berupa data kualitatif dan kuantitatif. Data kualitatif diperoleh dari hasil observasi, angket keaktifan, angket sikap, dan wawancara. Data kuantitatif didapat dari hasil penilaian prestasi belajar siswa pada materi hidrolisis garam yang meliputi aspek sikap, pengetahuan, dan keterampilan baik pada siklus I maupun siklus II.

Teknik analisis data pada penelitian ini menggunakan analisis deskriptif. Analisis data menggunakan tiga tahap yaitu reduksi data (pengelolaan data), penyajian data (mengorganisasikan data kedalam suatu bentuk tertentu sehingga datanya terlihat lebih utuh), dan triangulasi atau pemeriksaan keabsahan data dengan memanfaatkan sesuatu yang lain di luar data tersebut sebagai pembanding data [7].

\section{HASIL DAN PEMBAHASAN}

Penelitian tindakan kelas ini bertujuan untuk meningkatkan keaktifan dan prestasi belajar siswa kelas XI IPA 3 SMA N 2 Karanganyar pada materi hidrolisis garam dengan menerapkan model pembelajaran POE dilengkapi LKS berbasis drill and practice. Keaktifan siswa dalam proses pembelajaran meliputi visual activity, oral activity, listening activity, dan writing activity. Prestasi belajar yang diukur meliputi aspek sikap, pengetahuan, dan keterampilan.

Penelitian ini dilakukan dalam 2 siklus yaitu siklus I dan siklus II. Masingmasing siklus terdiri dari tahap perencanaan, tahap pelaksanaan tindakan, tahap pengamatan dan tahap refleksi [8]. Proses pembelajaran menggunakan model POE dilakukan dalam kelompok untuk memberikan kesempatan kepada siswa untuk bekerjasama, jujur, tanggung jawab dan disiplin dalam kelompoknya.

\section{Siklus I}

\section{a. Perencanaan}

Pada tahap perencanaan siklus I dilakukan penyusunan silabus, RPP, LKS, instrumen penilaian keaktifan siswa, serta instrumen prestasi belajar. Berdasarkan data silabus diketahui bahwa materi hidrolisis memiliki alokasi waktu 8 jam pelajaran (8 jp). Perincian pembelajaran pada siklus I yaitu 6 jp $(6 \mathrm{x}$ 45 menit) untuk penyampaian materi dan 2 jp (2 x 45 menit) untuk evaluasi siklus I.

\section{b. Pelaksanaan}

Tahap pelaksanaan siklus I terdiri atas 4 kali pertemuan, dengan 3 kali pertemuan untuk penyampaian materi dan 1 kali pertemuan untuk evaluasi siklus I. Pada pertemuan awal ini dilakukan kegitan praktikum untuk penilaian aspek keterampilan siswa. Praktikum diawali dengan guru memberikan apersepsi dan menjelaskan tujuan serta model pembelajaran yang akan dilakukan hari ini, lalu guru menjelaskan materi yang akan dipelajari secara singkat dan memberikan lembar prediksi kepada masing-masing siswa. Siswa menuliskan tentang prediksinya mengenai permasalahan yang ada pada lembar prediksi dan dikumpulkan kepada guru, setelah itu siswa memulai kegiatan praktikum. Praktikum ditutup dengan 
salah satu kelompok maju untuk mempresentasikan hasil praktikumnya. Setelah selesai praktikum, siswa diharuskan menulis laporan hasil praktikum kelompoknya masing-masing.

Pertemuan kedua dan ketiga hampir sama dengan pertemuan pertama, hanya saja pada pertemuan kedua dan ketiga tidak ada praktikum dan siswa belajar materi di kelas. Pada pertemuan terakhir atau pertemuan keempat, dilaksanakan evaluasi siklus I yang meliputi penilaian aspek pengetahuan dimana siswa harus menjawab soal ulangan dan waktu yang tersisa digunakan untuk mengisi angket penilaian diri.

\section{c. Pengamatan}

Hasil penilaian observasi dan analisis hasil tes pada siklus I dapat dibuat dalam beberapa kategori-kategori. Hasil penilaian sikap siswa dapat dibuat kategori seperti pada Gambar 1.

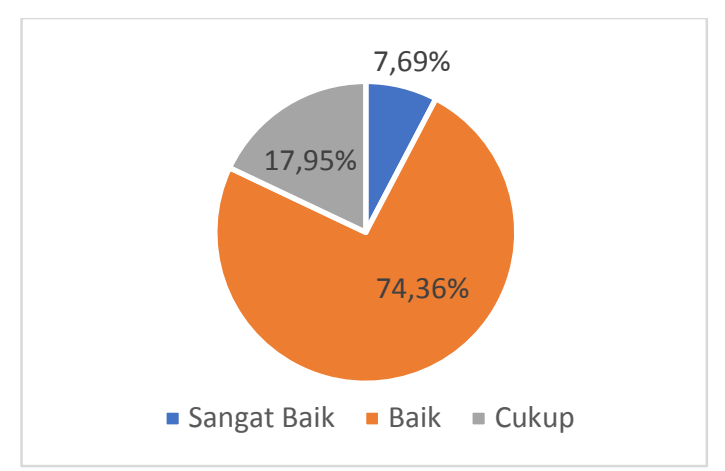

Gambar 1. Ketercapaian Aspek Sikap Siswa Siklus I

Gambar 1 menunjukkan jika secara umum capaian aspek sikap siswa sudah cukup baik hal itu ditunjukan dari jumlah siswa sangat baik dan baik melampaui target siklus I sebesar 75\%. Ada satu indikator sikap yaitu aspek jujur yang capaiannya masih di bawah target sehingga perlu dilanjutkan ke siklus II.

Hasil penilaian aspek pengetahuan bisa dilihat pada Gambar 2.

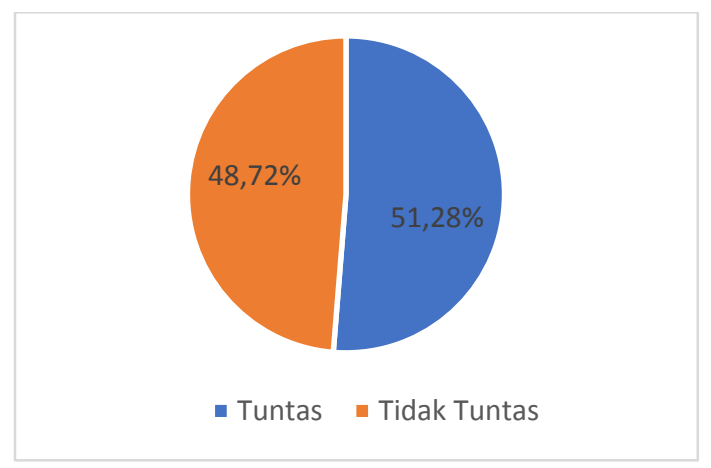

Gambar 2. Hasil Ketercapaian Aspek

Pengetahuan Siswa Siklus I

Gambar 2 menunjukkan bahwa siswa yang nilai yang tuntas masih di bawah target siklus I yaitu $70 \%$. Hasil siklus I terdapat dua indikator yang belum tuntas yaitu penentuan tetapan hidrolisis dan penentuan $\mathrm{pH}$ larutan garam, sehingga perlu dilanjutkan ke siklus II.

Hasil observasi menunjukkan penilaian aspek keterampilan seperti yang disajikan dalam Gambar 3.

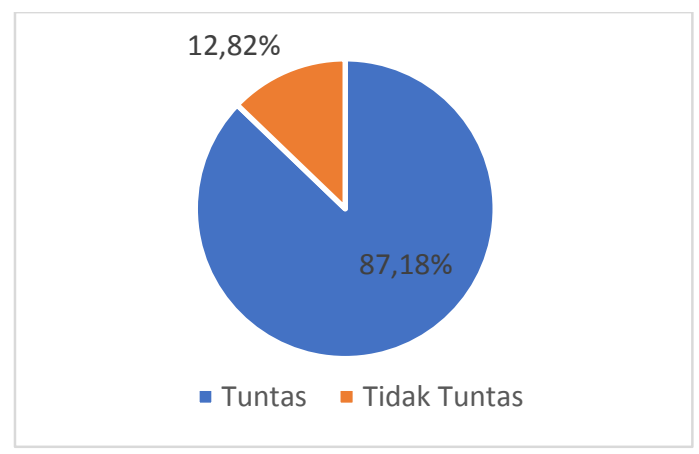

Gambar 3. Ketercapaian Aspek Keterampilan Siswa Siklus I

Pada penilaian aspek keterampilan, capaian siswa yang tuntas sudah mencapai target siklus 1 yaitu sebesar $70 \%$. Semua indikator pada aspek ini sudah mencapai target yang direncanakan sehingga untuk penilaian aspek keterampilam hanya dilakukan pada siklus I.

Hasil angket dan observasi keaktifan siswa dapat dilihat pada Gambar 4 berikut ini. 


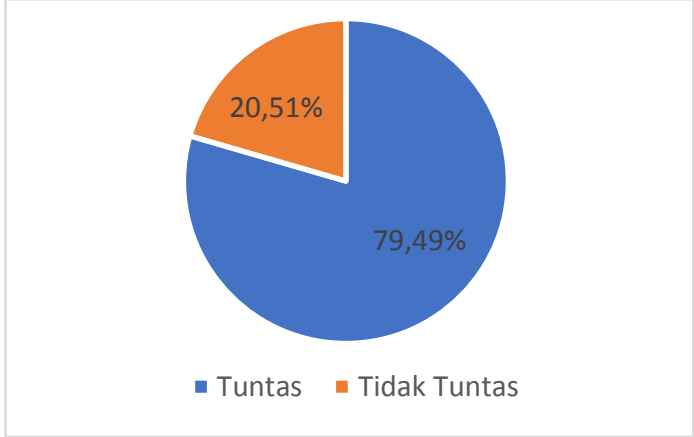

Gambar 4. Ketercapaian Aspek Keaktifan Siswa Siklus I

Gambar 4 menunjukkan jika secara umum capaian aspek keaktifan siswa sudah cukup baik hal itu ditunjukan dari jumlah siswa tuntas yang sudah mencapai target siklus I sebesar $75 \%$, namun ada satu indikator keaktifan yaitu oral activity yang capaiannya masih di bawah target sehingga perlu dilanjutkan ke siklus II.

\section{d. Refleksi}

Hasil pengamatan yang dilakukan menunjukkan masih terdapat aspek yang belum mencapai target yaitu aspek pengetahuan, sikap dan keaktifan. Oleh karena itu, perlu dilaksanakan siklus II yang diharapkan dapat mencapai target yang sudah ditentukan.

\section{Siklus II}

\section{a. Perencanaan}

Pada pelaksanaan siklus II ini lebih difokuskan untuk perbaikan terhadap kendala-kendala yang muncul pada siklus I. Materi yang diberikan juga fokus pada indikator-indikator yang belum mencapai ketuntasan yaitu menentukan tetapan hidrolisis garam dan menentukan $\mathrm{pH}$ larutan garam. Pemberian evaluasi juga terbatas pada soal dengan indikator-indikator yang belum tuntas saja. Guru lebih memfokuskan pada siswa yang hasil evaluasi siklus I mendapatkan nilai yang tergolong rendah dibandingkan temantemannya untuk perbaikan pada siklus II. Kelompok diskusi pada siklus II ini dibagi berdasarkan nilai yang telah didapat siswa pada evaluasi siklus I. Hal ini dilakukan agar siswa yang sudah tuntas di siklus I dapat membantu temannya yang belum tuntas dalam satu kelompok tersebut bisa tuntas dalam evaluasi siklus II.

\section{b. Pelaksanaan}

Siklus II ini dilaksanakan dalam 2 kali pertemuan, yaitu 1 kali pertemuan untuk penyampaian materi dan 1 kali pertemuan untuk evaluasi siklus II.

Pada pertemuan pertama, guru menjelaskan kepada siswa bahwa pembelajaran ini lebih difokuskan kepada materi yang belum dipahami pada siklus I yaitu pada indikator penentuan tetapan hidrolisis dan penentuan $\mathrm{pH}$ larutan garam. Guru memberikan soal diskusi agar siswa lebih memahami materi yang diajarkan, setelah itu kelompok yang sudah selesai diminta maju untuk mengerjakan soal di depan dengan kelompok lain bisa bertanya terkait hal yang belum dimengerti. Guru dan siswa bersama membuat kesimpulan di akhir pembelajaran.

Pada pertemuan kedua atau pertemuan terakhir dilaksanakan evaluasi siklus II yang terdiri atas tes aspek pengetahuan berupa 15 soal objektif dan sisa waktunya digunakan untuk mengisi angket penilaian diri.

\section{c. Pengamatan}

Hasil observasi dan analisis tes yang sudah dilakukan pada siklus II dapat dilihat dari hasil pada masingmasing aspek, yaitu aspek sikap, pengetahuan, dan keaktifan. Hasil observasi dan analisis angket aspek sikap siswa dapat dilihat pada Gambar 5.

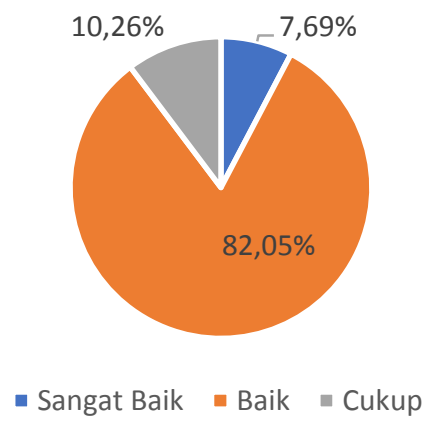

Gambar 5. Ketercapaian Aspek Sikap Siswa Siklus II 
Hasil yang disajikan pada Gambar 5 menunjukkan capaian siswa yang berkategori baik dan sangat baik sudah melampaui target yang direncanakan dan semua indikator juga sudah mencapai target sebesar $75 \%$, sehingga, penilaian aspek sikap dilakukan sampai siklus II ini.

Hasil tes aspek pengetahuan siklus II dapat dilihat pada Gambar 6 .

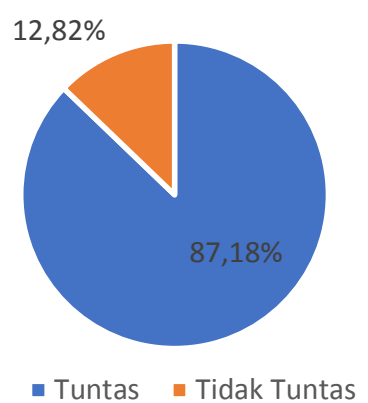

Gambar 6. Ketercapaian Aspek Pengetahuan Siswa Siklus II

Jumlah capaian aspek pengetahuan siklus ini sebesar $87,18 \%$, hasil ini sudah melampaui target sebesar $75 \%$. Semua indikator pada siklus ini juga sudah mencapai target yang sudah direncanakan sehingga penilaian aspek pengetahuan siswa diakhiri pada siklus II.

Hasil observasi dan analisis angket keaktifan siswa dapat dilihat pada Gambar 7.

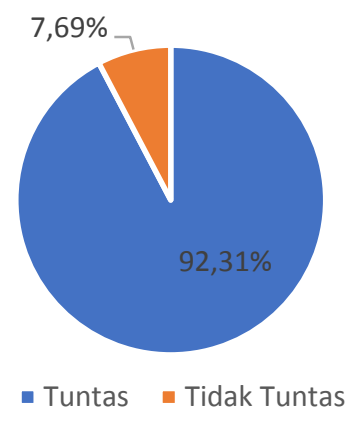

Gambar 7. Ketercapaian Aspek Keaktifan Siswa Siklus II

Gambar 7 menunjukkan jika secara umum capaian aspek keaktifan siswa sudah cukup baik hal itu ditunjukan dari jumlah siswa tuntas yang sudah mencapai target sebesar $75 \%$. Semua indikator pada aspek keaktifan juga sudah mencapai target sehingga penilaian aspek keaktifan diakhiri pada siklus II.

\section{d. Refleksi}

Berdasarkan data yang diperoleh pada siklus II, terlihat semua aspek meliputi aspek pengetahuan, sikap dan pertanyaan mengalami peningkatan capaian dan sudah melampaui target sehingga penelitian di akhiri pada siklus II.

\section{Perbandingan Hasil 2 Siklus}

Berdasarkan hasil observasi, angket, tes dan wawancara yang telah dilakukan selama proses pembelajaran dengan model POE yang dilengkapi LKS berbasis drill and practice diperoleh data bahwa model tersebut dapat meningkatkan keaktifan dan prestasi belajar pada materi hidrolisis garam. Keaktifan siswa dinilai dari angket keaktifan yang diberikan pada akhir siklus. Observasi dan wawancara dilakukan sebagai pembanding untuk mengecek keabsahan data yang diperoleh. Data ketercapaian keaktifan siswa siklus I dan II disajikan pada Gambar 8.

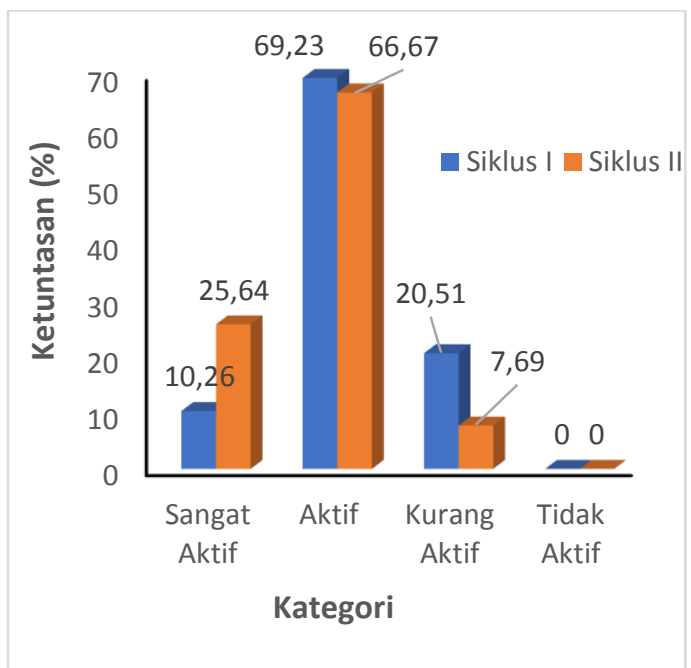

Gambar 8. Diagram Perbandingan Kategori Aspek Keaktifan Siklus I dan Siklus II

Berdasarkan Gambar 8, dapat dilihat bahwa keaktifan siswa mengalami peningkatan dari siklus I ke siklus II 
sebesar $12,82 \%$. Hal ini disebabkan oleh dengan penggunaan model POE membuat siswa mempunyai kesempatan yang lebih banyak untuk bertanya maupun mengungkapkan pendapatnya. Siswa juga menjadi lebih berani untuk menjawab pertanyaan dari guru karena meningkatnya rasa percaya diri mereka. Melalui model POE siswa dituntun untuk mengobservasi sendiri mengenai materi yang dipelajari, sehingga siswa akan lebih lama mengingat konsep yang ada. Pembelajaran dengan menggunakan model POE dapat meningkatkan kesempatan berharga siswa dalam mengkritik ide, menyampaikan pendapat dan mendukung perolehan pemahaman konseptual yang benar [9].

Variabel berikutnya dalam penelitian ini yaitu prestasi belajar yang meliputi aspek sikap, pengetahuan, dan keterampilan. Aspek sikap memiliki target sebesar $75 \%$ siswa tuntas. Sikap siswa yang diamati yaitu spiritual, jujur, disiplin, tanggungjawab, dan kerjasama. Cara penilaian aspek sikap berdasarkan Kurikulum 2013, yaitu dengan menggunakan modus atau nilai terbanyak. Kategori ketuntasan sikap terdiri dari sikap sangat baik dan sikap baik. Berikut dapat dilihat perbandingan kategori aspek sikap pada Gambar 9.

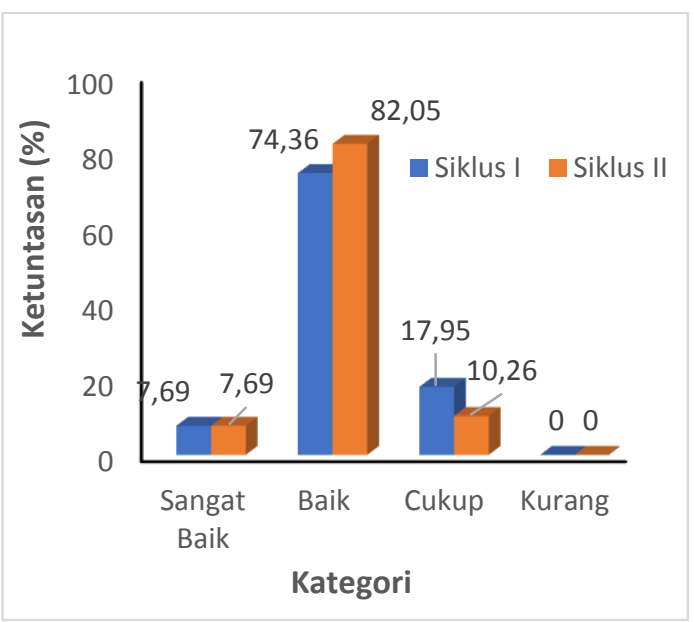

Gambar 9. Diagram Perbandingan Kategori Aspek Sikap Siklus I dan Siklus II

Pada siklus I pencapaian aspek sikap sebesar $82,05 \%$. Hasil ini sudah memenuhi target yang telah ditentukan, namun pada pelaksanaan siklus II tetap dilakukan penilaian aspek sikap dikarenakan masih ada indikator yang belum tuntas yaitu aspek jujur. Hal ini dilakukan dengan tujuan untuk mengetahui apakah sikap siswa mengalami peningkatan setelah adanya perbaikan pada proses pembelajaran. Hasil data yang diperoleh pada siklus II mengalami peningkatan menjadi $89,74 \%$.

Aspek kedua dalam prestasi belajar yaitu aspek pengetahuan. Pengamatan awal atau prasiklus pada penelitian ini dilakukan pada nilai ulangan harian materi hidrolisis pada tahun ajaran 2015/2016. Berdasarkan hasil kajian nilai tersebut diketahui bahwa ketuntasan materi hidrolisis belum mencapai $50 \%$ siswa tuntas. Target ketuntasan aspek pengetahuan pada penelitian ini yaitu $70 \%$. Pada siklus I terdapat 4 indikator yang harus dicapai, akan tetapi hasil dari siklus I menunjukkan bahwa masih ada 2 indikator yang belum tercapai dan ketuntasan siswa hanya mencapai $51,28 \%$. Presentase ketuntasan aspek pengetahuan siklus I dan siklus II ditunjukkan pada Gambar 10.

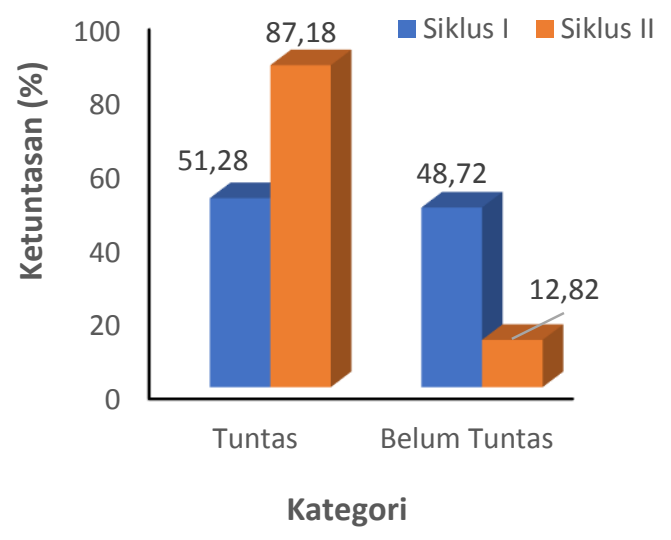

Gambar 10. Diagram Ketuntasan Aspek Pengetahuan Siklus I dan Siklus II

Pada siklus I diperoleh ketuntasan aspek pengetahuan sebesar 51,28\% atau sebanyak 20 siswa tuntas. Hasil ini belum mencapai target yang ditentukan namun sudah mengalami peningkatan jikan dibandingkan dengan tahun sebelumnya. Belum tuntasnya target 
pada siklus I ini dapat disebabkan karena siswa belum terbiasa dengan penggunaan model pembelajaran POE, oleh karena itu pembelajaran dilanjutkan ke siklus II untuk meningkatkan hasil aspek pengetahuan.

Hasil tes siklus II menunjukkan $87,18 \%$ atau sebanyak 34 siswa telah mencapai kriteria ketuntasan minimum. Penggunaan model pembelajaran POE efektif dalam meningkatkan prestasi belajar kimia pada siswa sekolah menengah [10]. Hal ini berarti hasil aspek pengetahuan pada siklus II telah mencapai target. Kenaikan aspek pengetahuan dari prasiklus ke siklus I dan siklus II dapat disebabkan oleh beberapa faktor, salah satunya yaitu perubahan kelompok yang terjadi pada siklus II. Siswa yang memiliki keaktifan dan nilai yang tinggi pada siklus I disebar merata ke dalam 8 kelompok. Siswa yang memiliki keaktifan tinggi akan mendapatkan nilai pengetahuan yang tinggi. Hal ini disebabkan oleh siswa yang rajin menulis hasil diskusi maka akan lebih mudah belajar dan apabila siswa semakin sering bertanya maka siswa akan semakin banyak memperoleh informasi baru yang belum diketahui sebelumnya.

Aspek terakhir pada prestasi belajar siswa adalah keterampilan siswa. Aspek ini diukur dengan menggunakan praktikum yang hanya dilakasanakan pada siklus I. Pelaksanaan praktikum hanya dilakukan pada siklus I dikarenakan keterbatasan waktu yang diberikan oleh pihak sekolah dalam melaksanakan praktikum. Hasil pencapaian siswa yang sudah melebihi target yang telah ditetapkan. Target yang ditetapkan pada aspek keterampilan adalah $70 \%$ dan pencapaian aspek keterampilan pada siklus I mencapai 87,18\%. Pencapaian pada setiap indikator juga sudah memenuhi target yang ditentukan.

Hasil penilaian yang diperoleh pada siklus II menunjukkan bahwa penelitian tindakan kelas ini berhasil karena semua aspek yang diukur telah mencapai target yang ditentukan. Peningkatan hasil dari siklus I ke siklus II ini disebabkan oleh: (1) adanya penguatan materi mengenai indikator yang belum tuntas sehingga siswa dapat lebih memperdalam pengetahuannya; (2) guru lebih memfokuskan perhatian kepada siswa yang mengalami kesulitan belajar dengan cara mendampingi dan memberikan penjelasan mengenai materi yang belum dipahami; dan (3) pengalaman siswa pada siklus I sehingga pada pembelajaran siklus II siswa sudah tidak bingung dan tidak banyak bertanya mengenai model pembelajaran POE yang digunakan.

Berdasarkan hasil tersebut, penelitian dengan menggunakan model pembelajaran Predict Observe Explain (POE) dilengkapi dengan LKS berbasis drill and practice dikatakan berhasil karena pada akhir penelitian semua aspek telah mencapai target yang ditetapkan. Penelitian ini dapat meningkatkan proses belajar siswa yang berupa keaktifan serta prestasi belajar siswa yang terdiri dari aspek sikap, aspek pengetahuan, dan aspek keterampilan.

\section{KESIMPULAN}

Berdasarkan hasil penelitian yang telah dilakukan, maka dapat disimpulkan bahwa penerapan model pembelajaran Predict Observe Explain (POE) dilengkapi LKS berbasis drill and practice pada materi hidrolisis garam kelas XI IPA 3 SMA Negeri 2 Karanganyar Tahun Pelajaran 2016/2017 dapat meningkatkan keaktifan dan prestasi belajar siswa. Persentase ketercapaian keaktifan siswa pada siklus I sebesar $79,49 \%$ menjadi $92,31 \%$ pada siklus II. Peningkatan prestasi belajar siswa juga terlihat dari hasil prestasi belajar aspek sikap sebesar 82,05\% meningkat menjadi $89,74 \%$. Aspek pengetahuan sebesar $51,28 \%$ menjadi $87,18 \%$. Ketercapaian aspek keterampilan sebesar $87,18 \%$.

\section{UCAPAN TERIMAKASIH}

Penelitian ini dapat terselenggara dengan baik karena bantuan dari berbagai pihak. Oleh karena itu penulis ingin mengucapkan terimakasih kepada Kepala SMA Negeri 2 Karanganyar, Ibu Dra. Hj. Suliyastuti, MM atas izin yang diberikan kepada penulis untuk melakukan penelitian, dan kepada guru 
kimia kelas XI Bapak Alimin Sutanto, S.Pd., M.Pd. yang telah memberikan bimbingan selama penelitian, serta kepada siswa-siswi kelas XI IPA 3 SMA Negeri 2 Karanganyar tahun pelajaran 2016/2017 yang telah membantu penulis dalam menyelesaikan penelitian ini.

\section{DAFTAR RUJUKAN}

[1] Nasution, S. (2004). Kurikulum Berbasis Kompetensi. Bandung: PT Remaja Rosdakarya.

[2] Shantiy, Mulyani, B., Utami, B., (2015). Jurnal Pendidikan Kimia. 4(4). 139-146.

[3] Hong, JC., dkk. (2014). Computers and Education. 72. 110-120.

[4] Suyono dan Hariyanto, (2015). Belajar dan Pembelajaran. Bandung: PT Remaja Rosdakarya.

[5] Ipek, H., dkk. (2010). Social and Behavioral Science. 2. 648-653.
[6] Nugroho, SA., Redjeki, T., Mulyani, S. (2014). Jurnal Pendidikan Kimia. 3 (4). 93-99.

[7] Arikunto, S., Suharjono dan Supardi. (2006). Penelitian Tindakan Kelas. Jakarta: Bumi Aksara.

[8] Waryuman, D., Rehendi, D., dan Sutarno, H. (2010). Kumpulan Skripsi Pendidikan Ilkom, HIm 3640. Universitas Pendidikan Indonesia, Bandung.

[9] Ayhan, C. dan Yavuz, D. (2013). A Journal of Educational Strategies, Issues and Ideas. 86(1): 1-10.

[10] Sreerekha, Raj, A., dan Sankar, S. (2016). International Journal of Education \& Teaching Analytics. 1 (1). 1-5. 